\title{
IDENTIFYING LANDSCAPE VALUES AND STAKEHOLDER CONFLICTS FOR THE PROTECTION OF LANDSCAPE MULTIFUNCTIONALITY: THE CASE OF EKŞISU WETLANDS (TURKEY)
}

\author{
BAYLAN, E. ${ }^{{ }^{*}}-$ KARADENIZ, N. $^{2}$ \\ ${ }^{I}$ Department of Landscape Architecture, Faculty of Architecture-Design \\ Van Yüzüncü Yll University, Van, Turkey \\ (phone: +90-5367034389) \\ ${ }^{2}$ Department of Landscape Architecture, Faculty of Agriculture \\ Ankara University, Ankara, Turkey \\ (email: nkaradeniz@ankara.edu.tr) \\ *Corresponding author \\ e-mail:emelbaylan@yyu.edu.tr \\ (Received 28 $8^{\text {th }}$ Jul 2017; accepted $6^{\text {th }}$ Dec 2017)
}

\begin{abstract}
The aim of this study was to identify and define the multiple benefits that Ekşisu Wetlands (Upper-Euphrates Basin) provides to its local stakeholders, and the major problems and sectors/stakeholders in conflict that shape the area in order to inform the collaborative landscape planning process for the wetlands. Landscape value mapping and analysis of the stakeholders and conflicts between them were employed, as were statistical analysis of the linkages between the perceived benefits of the landscape and land use/land cover characteristics. Stakeholder analysis showed that the governmental institutions have more decision-making power than user group of the wetlands. Drainage control, over grazing, abstraction of sand-gravel from the river bed, environmental pollution and the lack of will to use the available legislative and administrative mechanisms are the primary factors that threaten the Ekşisu Wetlands and its multifunctionality. Among the landscape values examined, future value was considered the most important by the stakeholders. Two sets of landscape service bundles were identified; use and non-use landscape values; option landscape values- that are linked to Ekșisu Wetlands. Conflict between the nature conservation and agriculture sectors and, conflict between the stakeholders over provisioning, regulatory, and cultural services are two primary conflict issues that were identified in the drainage basin of the wetlands. Habitat protection and improvement, and protecting and improving the area's regulating and cultural functions were proposed as priorities for the collaborative management of the area.
\end{abstract}

Keywords: landscape function; landscape services; collaborative landscape planning; wetland management; landscape service bundles

\section{Introduction}

A landscape is a dynamic system-the result of diverse landscape functions-from which communities obtain multiple landscape services that are vital for human wellbeing and community sustainability (Kienast et al., 2009). Although landscape functions and their associated services are the primary elements necessary for the sustainability of individuals and communities, and quality of life, many of these functions are currently under threat (MEA, 2005; Carpenter et al., 2006; Daily et al., 2009).

Before the 1990s, landscape research and management practices focused primarily on a single function and landscape service (de Groot, 2006); however, relative to population growth, economics, environmental degradation, climate change, and 
sustainability, any landscape planning and management approach that focuses only on a single function and single benefit of a landscape is inadequate and cannot satisfy the varying needs and demands of all landscape stakeholders (Fry, 2001). The diverse and increasing demands on landscapes result in their degradation and conflicts between their stakeholders that vary in scale and context. A stakeholder is anybody who can affect or is affected by an organisation, strategy, project, change or usage. They can be internal or external and they can be at senior or junior levels (Anonymous, 2017). Stakeholder conflicts generally arise from the competing interests of a landscape's multiple stakeholders and are also related to top-down planning approaches that ignore local community and stakeholder needs. As such, since 2000 the importance given to and advocacy for landscape multifunctionality (Fry, 2001; de Groot, 2006; Potschin and Haines-Young, 2006), and inclusive participatory approaches to landscape planning have increased substantially (Luz, 2000; Buchecker, 2003; Selman, 2004).

In terms of multifunctionality and related landscape services, wetlands are among the most critical ecosystems on Earth. Covering $0.6 \%$ of Earth's surface, wetlands provide multiple landscape services to communities to a much greater degree than other types of landscapes (Mitsch and Gosselink, 2000; de Groot et al., 2006); however, due to the relative undesirability of wetlands, the competing and conflicting interests of wetland stakeholders, and ignorance concerning wetland ecological functions and public benefits, wetland ecosystems and their multifunctionality have been put under great pressure by human activity throughout history (Turner et al., 2000; Finlayson et al., 2005; de Groot et al., 2006). In order to protect the multifunctionality of wetlands via a collaborative decision-making process, the importance and value of the benefits provided by wetlands to local communities and stakeholders, as well as the stakeholders' conflicting interests must be identified (Brander et al., 2006; de Groot et al., 2006).

In Turkey, wetland landscapes are subjected to increasing threats and conflicts arising from short-term economic benefit-oriented land-use policies and local practices (Karadeniz et al., 2009; Uçak et al., 2014; Curebal et al., 2015). Ekşisu Wetlands in Turkey's northeast Anatolian Region is among the many facing such issues (Aslay and Kandemir 2009; Doğan et al., 2015). The aim of the present study was to identify the links between Ekşisu Wetlands' stakeholders and the links between those stakeholders and the wetlands, so as to inform a collaborative planning process aimed at protecting the multifunctionality of Ekşisu Wetlands. Based on the findings, we provide a discussion of the required tools and framework, with respect to their relevance to collaborative landscape planning, and recommendations for the collaborative stakeholder structure and possible strategies for ensuring the sustainability of Ekşisu Wetlands' multifunctionality.

\section{Landscape multifunctionality}

Based on the interlinked and multidimensional (temporal, biogeophysical, social, cultural, and economic) nature of today's landscapes, there is a growing consensus that landscapes are multifunctional systems (Brandt et al., 2000; Naveh, 2001; de Groot, 2006; Haines-Young and Potschin, 2010). In terms of sustainability, landscape multifunctionality is indicative of the actual or potential fulfillment of several functions, and the provision of multiple benefits (Wiggering et al., 2006). Recent research on landscape multifunctionality has focused on multiple related concepts, including landscape functions, landscape services, and ecosystem services. 
Landscape function refers to the capacity of a landscape to provide material and immaterial goods and services that meet the needs and demands of communities-directly or indirectly-and varies according to a landscape's characteristics. Landscape characteristics shape landscape functions, which are considered landscape services when people use and assign importance and value to them, according to the benefits they provide (Wiggering et al., 2006; Kienast et al., 2009; Selman, 2009; Termorshuizen and Opdam, 2009; Willemen et al., 2010; Hermann et al., 2011; Vallés-Planells, 2014). Landscape functions and their associated landscape services are categorized as follows: 1. Production functions: provision of natural products obtained from the ecosystem, such as nutrition, raw materials and energy; 2. Regulation and maintenance functions: regulation and maintenance services are the benefits provided by ecosystem processes, and include water purification, habitat and gene pool protection, and life-support systems; 3. Cultural functions: cultural services via physical, intellectual, spiritual, symbolic, and other interactions with biota, ecosystems, and land-/seascapes (MEA, 2005; CICES, 2017).

Landscape structure and function affect how individuals and communities regard the landscape, but are affected by human activity (Nassauer, 1995). A landscape and its assigned value informs individuals' types of land use, and choices, needs, and expectations related to where and how they live and work (Kaltenborn and Bjerke, 2002; Oliveira and Dineboska, 2004; Stewart et al., 2004; Oñate and Peco, 2005; Manzo and Perkins, 2006). Rolston and Coufal (1991), Brown (2006, 2005) and Brown and Raymond (2007) and defined 12 landscape values that focus on multiple landscape benefits, ranging from functional to symbolic $(Z u b e, 1987)$ such as aesthetic, heritage or intrinsic.

A comprehensive participatory approach that takes into consideration the multiple benefits of landscapes, and the multiple interests and opinions of all landscape stakeholders is needed to formulate optimal management strategies for the protection of the multifunctionality of landscapes. As such, there is an increasing emphasis on analysis and mapping of landscape services (MEA, 2005; Carpenter et al., 2006; Fisher, 2008; Daily et al., 2009; Bollinger and Kienast, 2010; Bollinger et al., 2011) and, identification of conflicts between stakeholders (Wondolleck and Yaffee, 2000; de Groot, 2006; Manzo and Perkins, 2006 ), and identification of the importance and assigned value of landscape benefits by multiple stakeholders, as powerful tools for use in a participatory landscape planning process (Brown, 2006; Brown and Raymond, 2007; Alessa et al., 2008; Fagerholm and Käyhkö, 2009; Raymond et al., 2009).

\section{Addressing landscape values and conflicts through collaborative landscape planning}

The limits of the traditional top-down landscape planning approach for effectively addressing the challenges of maintaining landscape multifunctionality highlight the need for participatory approaches. Consequently, the importance of a participatory planning process that facilitates stakeholder involvement, and consensus, negotiation, and collaboration between all relevant stakeholders has become widely recognized (Johnson et al., 2002; Mostert, 2003; Tippett et al., 2005; Giordana et al., 2007; PahlWostl et al., 2007).

Collaborative planning is a promising new method for resolving conflicts between landscape stakeholders, based on shared values, and compromise and negotiation of joint goals for spatial planning and natural resource management. The process requires technical and social tools that facilitate equal and active involvement of all stakeholders 
in a joint decision-making process (Grimble and Wellard, 1997; Margerum, 2002; Overall, 2005; Innes and Booher, 2010); therefore, collaborative planning is both a technical and a social process. As a technical process, collaborative landscape planning deals with the sustainability of landscapes, whereas as a social process, it emphasizes consideration of the perspectives of multiple stakeholders, their interests/demands, and the conflicts between them in an effort to arrive at democratic solutions to conflicts via a bottom-up, active participatory process (Healey, 2003; Selman, 2004; de Groot, 2006; Termorshuizen and Opdam, 2009).

Via collaboration, negotiation, and conflict management based on trust, public responsibility for and a sense of ownership by stakeholders of landscape planning and management the decision-making process is greatly improved (Arnstein 1969; Selin and Chevez, 1995; Dijkstra et al., 2011). Collaborative planning is a comprehensive and strategic process for achieving joint formulation of shared goals by the multiple stakeholders of a planning area (Sabatier et al., 2005; Ferreyra and Beard, 2007; Margerum, 2002).

\section{Materials and Methods}

\section{Study area}

Ekşisu Wetlands is located $11 \mathrm{~km}$ east of Erzincan City Center in the northeastern Anatolia Region of Turkey. At an altitude of 1140-1160 m, it is bordered by the Keşiş Mountains to the north and the Erzincan-Erzurum Highway to the south (Figure 1).

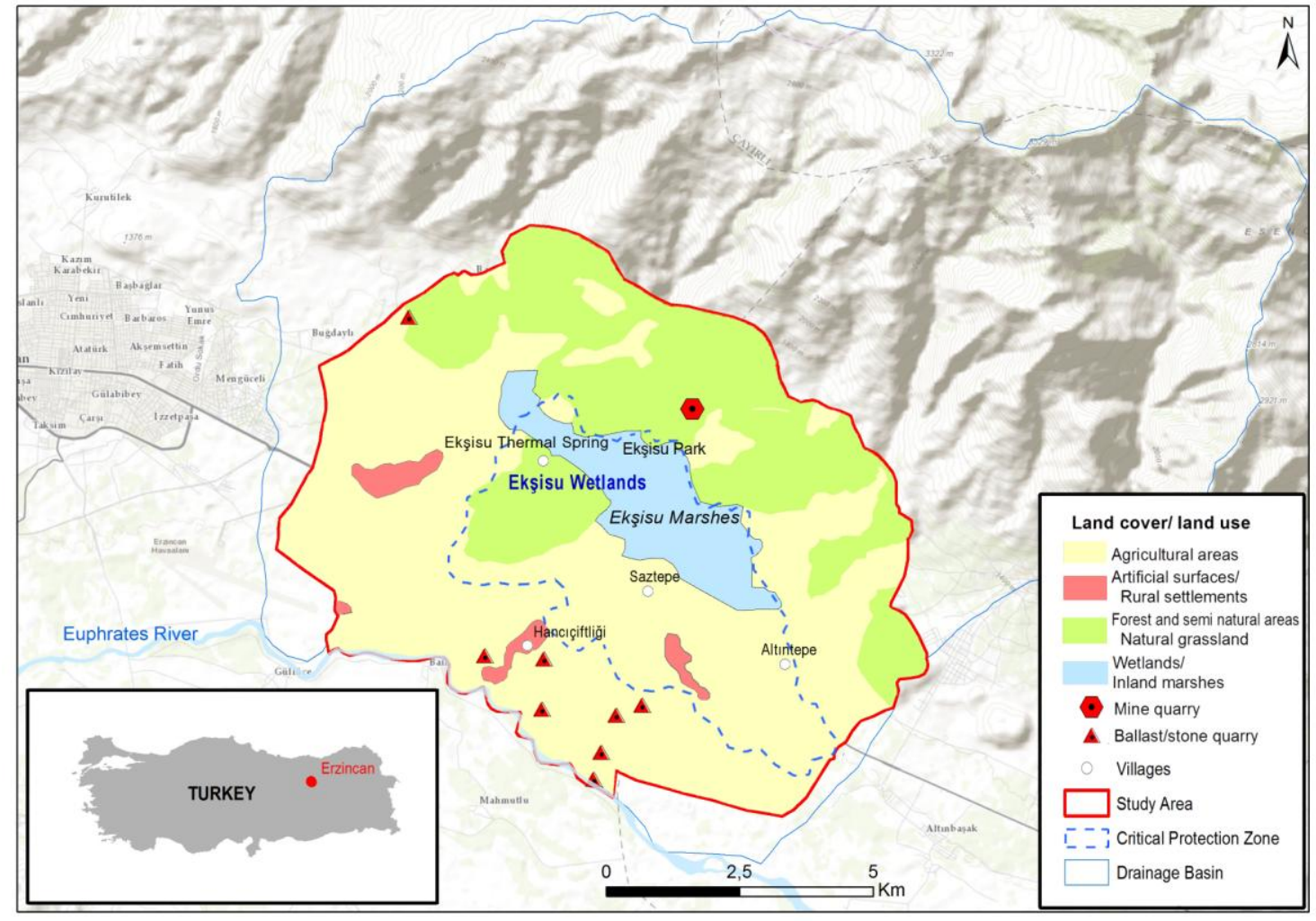

Figure 1. Location of Ekşisu Wetlands and LULC types (source: ESRI Topographic Base Maps 2017 and developed from CORINE Land Cover, 2012) 
Ekşisu Wetlands encompasses 8736 ha. Ekşisu Wetlands is under the administrative control of the towns Erzincan Central and Üzümlü. Ekşisu Wetlands is also approximately $5 \mathrm{~km}$ from the Euphrates River and lies on the North Anatolian Fault Line, making it part of Turkey's first-degree fault zone. The area, including the buffer zone, primarily contains saltwater marshes, meadows and agricultural fields. Alluvial soil is dominant in the study area (Akkan, 1964; Hayli, 2002; Akyıldız and Kılıç, 2006; Anonymous, 2014). Ownership of the land is both private and governmental. The area has been declared a $1^{\text {st }}$-Degree Natural Site area by the former Sivas Regional Board for Cultural and Natural Heritage Preservation. The Turkish Ministry of Forest and Water Affairs, General Directorate of Nature Conservation and National Parks and its local branch have primary responsibility for its management. Climatically, a typical east Anatolia continental climate prevails in the area and surroundings. The area has hot and dry weather during summer; the most hot month is August and the mean temperature in this month is $31,9{ }^{\circ} \mathrm{C}$ [1929-2016] and is cold and snowy during winter; the coldest month is January and the mean temperature in this month is $-7,2^{\circ} \mathrm{C}$ [1929-2016] w. Based on observations since 1929 , the annual mean temperature is $10,9{ }^{\circ} \mathrm{C}$. Snowfall begins in late October and lasts until April. In general, precipitation is highest in spring (from April to June, but primarily in April and May) and lowest in summer (especially in August) (Kaya, 2011; Anonymous, 2017).

Ekşisu Wetlands is an ecologically valuable landscape that provides feeding, roosting, and nesting sites for thousands of migratory and resident birds, as well as plant genetic materials for research. In all, 85 bird, 13 butterfly, 8 reptile, and 13 mammal species have been recorded in Ekşisu Wetlands. Based on these numbers, the area is ranked number 1 of the 263 Important Nature Areas of Turkey and is among the 184 Important Bird Areas of Turkey Ekşisu Wetlands is the only habitat in the world for the globally threatened plant species Soncus erzincanicus. The study area is also where the nationally threatened species Grus grus, Himantopus himantopus, Aythya nyroca, and Ixobrychus minutus breed (Akyıldız and Kılıç, 2006; Yeniyurt et al., 2011).

The primary LULC types in the study area include such agricultural areas as nonirrigated and permanently irrigated arable lands, vineyards, and mixed orchards and pastures, as well as natural grasslands, inland marshes, rural settlements, and mineral extraction sites (Figure 1). Altintepe and Saztepe tumuli, which are located in the south and southeast of the study area, include archeological sites from the Urartu Period (Akyıldız and Kılıç, 2006; Yeniyurt et al., 2011).

\section{Landscape inventory, analysis, and evaluation}

Baseline data on the current state of the natural and cultural processes, and assets of Ekşisu Wetlands, including its functional capacity, and present and foreseeable problems and conflicts related to land usage were inventoried and collated. To gain an overview of the landscape, the current state of its climate, topography, hydrology, soils, flora and fauna, and sociocultural and demographic characteristics were inventoried. Next, data obtained from government-sponsored research, academic studies (e.g. Akkan, 1964; Hayli, 2002; Akyıldız and Kılıç, 2006; Aslay and Kandemir, 2009), field visits, and community workshops conducted by the researchers were collated.

\section{Stakeholder and problem analysis}

Stakeholder and problem analyses were performed to identify groups and/or institutions that have a direct or indirect relationship with Ekşisu Wetlands that, directly 
or indirectly, influence, are in conflict with, and degrade Ekşisu Wetlands functions. Data from earlier studies (e.g. Hayli, 2002; Anonymous, 2005; Akyıldız and Kıliç, 2006; Aslay and Kandemir, 2009; Anonymous, 2010; Baylan, 2012; Anonymous, 2014) on Ekşisu Wetlands, and data of the stakeholders, problems related with the sustainability of Ekşisu Wetlands and conflicts between the stakeholders obtained from 1- day workshop on stakeholder and problem analysis and from field trips to the area were integrated. A 1-day workshop was conducted with 45 representatives and technical staff from the Erzincan Provincial Directorate of Forest and Water Affairs, State Water Affairs 82nd Branch Office, the Erzincan Provincial Directorate of Food, Agriculture, and Livestock, Erzincan University, Northeast Anatolia Development Agency, the Erzincan Governor's Office, mayors from the surrounding municipalities, village heads (muhtars), farmers, and agriculture and irrigation associations. The workshop participants were invited with the cooperation of the Erzincan Governor's Office. During the 1-day workshop, problems and conflicts associated with Ekşisu Wetlands were analyzed via root-cause analysis (Rooney and Heuvel, 2004), in an effort to identify the origins of the study area's degradation and threats. The analysis was conducted using brainstorming, joint thinking, and consensus, with the help of facilitators. The end result of the analysis was the creation of a problem tree.

\section{Spatial data analysis, landscape value associations, and spatial multifunctionality}

Mapping and analysis of the values Ekşisu Wetlands' stakeholders and communities assigned to the landscape were conducted. Initially, theoretical considerations, practical approaches, and implementations of landscape value mapping and analysis were examined in preparation for the study. The local Ekşisu Wetlands stakeholders chose 12 landscape values for the study. The values and analysis were based on research by Brown and Raymond (2007), Alessa et al. (2008) and Zhu et al. (2010). Value mapping consisted of preparation of a plain topographic map of the area (scale: 1:150,000) for each of the 12 landscape values. Statements and associated descriptions for each landscape value were written on each of the topographic maps.

The field study phase consisted of participatory mapping performed in a workshop format at the study area. First, the participants watched a short presentation on landscape values and the steps to be followed during the mapping process. Then, 45 representatives of national and local level governmental institutions, and municipalities responsible for management of the area, civil society organizations, researchers, farmers, and village heads scored each value on the maps using colored dots (yellow: 5 points; blue: 10 points; green: 20 points; orange: 50 points). Each landscape value map included 5 locations in and around Ekşisu Wetlands, and each participant could assign a maximum of 100 points per map. The surveyed landscape values are described in Table 1. Data collected during the workshop were inserted into digital data tables, and the locations of the mapped landscape value points were digitized using ArcView v.10.2.

In order to describe the spatial intensity of the landscape values, density surfaces were generated from point data layers using the kernel density function in ArcView Spatial Analyst. The kernel density output cell size was set to $100 \mathrm{~m}$ and the search radius was set to $1000 \mathrm{~m}$. The identified point density and value importance clusters were converted into raster form. Point density clusters were categorized into 7 classes via natural breaks classification, which was used to visualize the distribution of importance by location per landscape value in the area. 
Table 1. Surveyed Ekşisu Wetlands landscape values (Brown and Raymond, 2007)

\begin{tabular}{|c|c|c|c|}
\hline $\begin{array}{l}\text { Landscape } \\
\text { Value }\end{array}$ & Description & $\begin{array}{l}\text { Landscape } \\
\text { Service } \\
\text { Category }\end{array}$ & $\begin{array}{l}\text { Abbre- } \\
\text { viation }\end{array}$ \\
\hline Aesthetic value & $\begin{array}{l}\text { I value this area because of its pleasing natural } \\
\text { beauty, scents, and sounds. }\end{array}$ & Cultural & CAest \\
\hline Economic value & $\begin{array}{l}\text { I value this area because of its economic } \\
\text { benefits, e.g. income-generating activities, } \\
\text { such as agriculture and tourism. }\end{array}$ & Provisioning & PE \\
\hline $\begin{array}{l}\text { Recreation } \\
\text { value }\end{array}$ & I value this area for outdoor activities and leisure. & Cultural & CR \\
\hline $\begin{array}{l}\text { Life-sustaining } \\
\text { value }\end{array}$ & $\begin{array}{l}\text { I value this area because it helps sustain } \\
\text { human life and/or is important for air, water, } \\
\text { and soil quality. }\end{array}$ & Regulating & RLS \\
\hline $\begin{array}{l}\text { Knowledge } \\
\text { value }\end{array}$ & $\begin{array}{l}\text { I value this area because of its role in } \\
\text { environmental education. }\end{array}$ & Cultural & CK \\
\hline $\begin{array}{l}\text { Biological } \\
\text { diversity value }\end{array}$ & $\begin{array}{l}\text { I value this area because of its role in } \\
\text { supporting biodiversity, e.g. plants, animals, } \\
\text { and aquatic organisms. }\end{array}$ & Regulating & RB \\
\hline Spiritual value & $\begin{array}{l}\text { I value this area because it has spiritual } \\
\text { significance and/or is a sacred place. }\end{array}$ & Cultural & CS \\
\hline Intrinsic value & $\begin{array}{l}\text { I value this area independent of any thoughts } \\
\text { about it, and whether or not I use it; its value } \\
\text { is its existence. }\end{array}$ & Cultural & CI \\
\hline Heritage value & $\begin{array}{l}\text { I value this area because of its relationship to } \\
\text { natural and human history. }\end{array}$ & Cultural & $\mathrm{CH}$ \\
\hline Future value & $\begin{array}{l}\text { I value this area because it will allow future } \\
\text { generations to benefit from it, as we do in the } \\
\text { present. }\end{array}$ & Cultural & $\mathrm{CF}$ \\
\hline $\begin{array}{l}\text { Therapeutic } \\
\text { value }\end{array}$ & $\begin{array}{l}\text { I value this area because it improves physical and } \\
\text { psychological wellbeing. }\end{array}$ & Cultural & CT \\
\hline $\begin{array}{l}\text { Wilderness } \\
\text { value }\end{array}$ & I value this area because it is not man made. & Regulating & $\mathbf{R W}$ \\
\hline
\end{tabular}

Principal component analysis (PCA) and factor analysis were employed using IBM SPSS Statistics for Windows v.24.0 (IBM Corp., Armonk, NY, USA) to identify any associations between the mapped landscape values in the area. In addition, CORINE Land Cover (CLC) (2012) level 1 categories were used to analyze the spatial associations and co-occurrence of assigned landscape values in spatial scale to determine the links between LULC types and associated landscape values in an effort to understand the multifunctionality of the area. As such, a one-way ANOVA was conducted to compare the effects of primary LULC types on landscape value assignment in wetlands, natural grasslands, and agriculture categories in the study area. With this aim, factor scores of each location has been recorded as different variables and then based on the scores, the change between scores of LULC types has been analyzed. 


\section{Conflict analysis}

Conflict analysis was performed using data obtained from previous phases of the study, so as to identify the study area's conflicting interests, conflicting landscape services, and conflicting stakeholders. The conflict analysis considered and included the stakeholders, and their level of use/interest and influence on decisions regarding the management of the landscape, LULC types in Ekşisu Wetlands, and the values the stakeholders assigned to the landscape services, as well as the ongoing degradations and degradation risks on the landscape functions and services of the Ekşisu Wetlands (Figure 2). The conflicting stakeholders, uses of the landscape, and landscape service conflicts were visualized via symbols and indicated by zig-zag lines (Mason and Rychard, 2005) in the conflict figure (Figure 7).

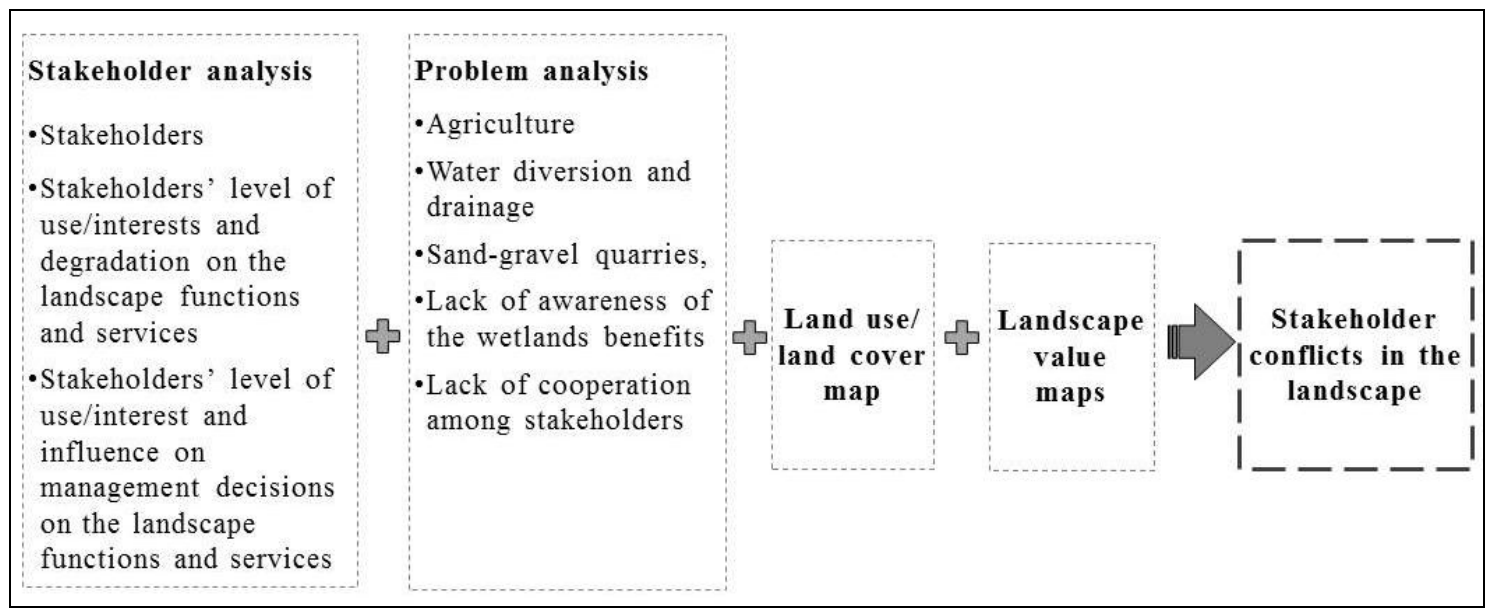

Figure 2. The conflict analysis framework

\section{Results}

\section{Stakeholders, pressures, and problems related to landscape function}

Stakeholder analysis showed that there are multiple stakeholders with varying interests, influence, and power concerning the use and management of Ekşisu Wetlands (Table 2) and (Figure 3). Farmers/landowners, visitors, national and local level governmental institutions, the sand-gravel quarry sector, responsible for the management of water and agricultural resources, and natural habitats, and municipalities were the primary stakeholders with direct interests in and influence on the study area and its management.

Since the 1950s, the provincial branch of the General Directorate of State Water Affairs (SWA) has used drainage canals in the study area for drainage control which is the primary factor that threaten Ekşisu Wetlands' landscape functions, as a result of changes in the hydrological cycle, land degradation, and habitat fragmentation in the area and its surroundings. In 2011 local farmers burned 160 ha of reed field in order to obtain agricultural land, which also caused habitat destruction in the area. Another important problem in the area is pollution. Discharged domestic sewage from surrounding villages and industrial solid waste and sewage (from mines and stone quarries), and waste generated by recreational activity are the primary sources of pollution in the study area. Solid waste disposal was reported to be a factor threatening 
Soncus erzincanicus, in addition to overgrazing, which causes damage to habitat and dries vegetation (Akyıldız and Kılıç, 2006; Aslay and Kandemir, 2009; Yeniyurt et al., 2011; Baylan, 2012). Since 2009, sand and gravel quarry has become an important problem on the south part of the area where the Euphrates River borders the buffer zone of the wetlands.

Table 2. Stakeholders of Ekşisu Wetlands

\begin{tabular}{|c|c|c|}
\hline $\begin{array}{l}\text { Ekşisu Wetlands } \\
\text { Stakeholders and } \\
\text { their roles related }\end{array}$ & \multicolumn{2}{|c|}{ Institutions } \\
\hline \multirow[t]{2}{*}{ 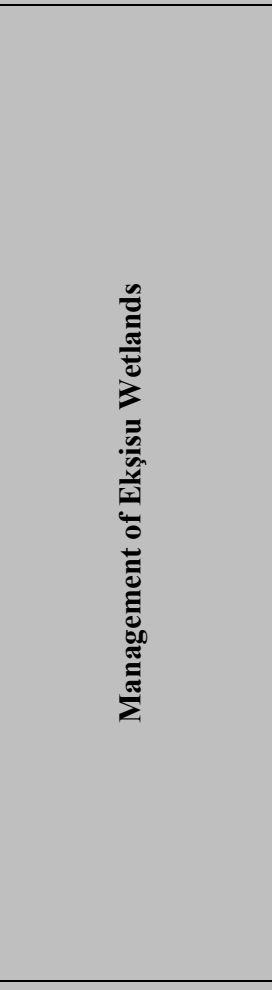 } & $\begin{array}{l}\text { Governmental Institutions - Central } \\
\text { Level } \\
\text { - Turkish Ministry of Forestry and } \\
\text { Water Affairs (MFWA) } \\
\text { - Turkish General Directorate of State } \\
\text { Water Affairs (SWA) } \\
\text { - Provincial Directorate of the } \\
\text { Turkish General Directorate of } \\
\text { Nature Conservation and National } \\
\text { Parks (GDNCNP) } \\
\text { - Sensitive Ecosystems Branch } \\
\text { Directorate } \\
\text { - Turkish Ministry of the Environment } \\
\text { and Urbanism (MEU) } \\
\text { - Turkish Ministry of Culture and } \\
\text { Tourism (MCT) } \\
\text { - Turkish Ministry of Food, } \\
\text { Agriculture, and Livestock (MFAL) }\end{array}$ & $\begin{array}{l}\text { Governmental Institutions - Local level } \\
\text { - Erzincan Governor's Office } \\
\text { - Provincial Branch of SWA: Regional } \\
\text { Directorate } 82 \\
\text { - Provincial Directorate of GDNCNP; } \\
\text { - Wetlands Branch Directorate } \\
\text { - Local Wetlands Commission } \\
\text { - Provincial Directorate of MEU } \\
\text { - Provincial Directorate of MCT } \\
\text { - North-Eastern Anatolia Development } \\
\text { Agency (NEADA) } \\
\text { - Provincial Directorate of MFAL }\end{array}$ \\
\hline & $\begin{array}{l}\text { Local municipalities/authorities } \\
\text { - Erzincan Municipality } \\
\text { - Üzümlü Municipality } \\
\text { - Akyazı Municipality } \\
\text { - Village Heads (muhtars) }\end{array}$ & $\begin{array}{l}\text { Civil Society Organizations } \\
\text { - Turkish Chamber of Agriculture } \\
\text { - Nature conservation NGOs } \\
\text { (national and local level) } \\
\text { - Union of Sheep Breeders } \\
\text { - Hunting Association } \\
\end{array}$ \\
\hline 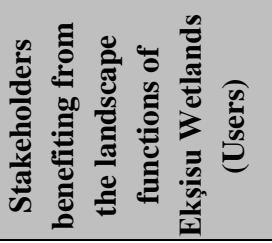 & \multicolumn{2}{|c|}{$\begin{array}{l}\text { - Local community } \\
\text { - Land owners/farmers and sheep and cattle breeders } \\
\text { - Hunters and illegal hunters } \\
\text { - Recreationists/Tourists } \\
\text { - Researchers } \\
\text { - Private sand- gravel quarry firms }\end{array}$} \\
\hline
\end{tabular}

The analysis quadrant for the influence (power) level on the management decisions for area and use/interest level of the stakeholders in the area shows that national and local governmental institutions have more decision-making power than user group of Ekşisu Wetlands (Figure 3); however, the current pressures and the threats to Ekşisu Wetlands indicate that those national and local governmental institutions that manage the area are not using the available legislative and administrative mechanisms or building a collaborative management process to ensure the sustainability of the wetlands. 


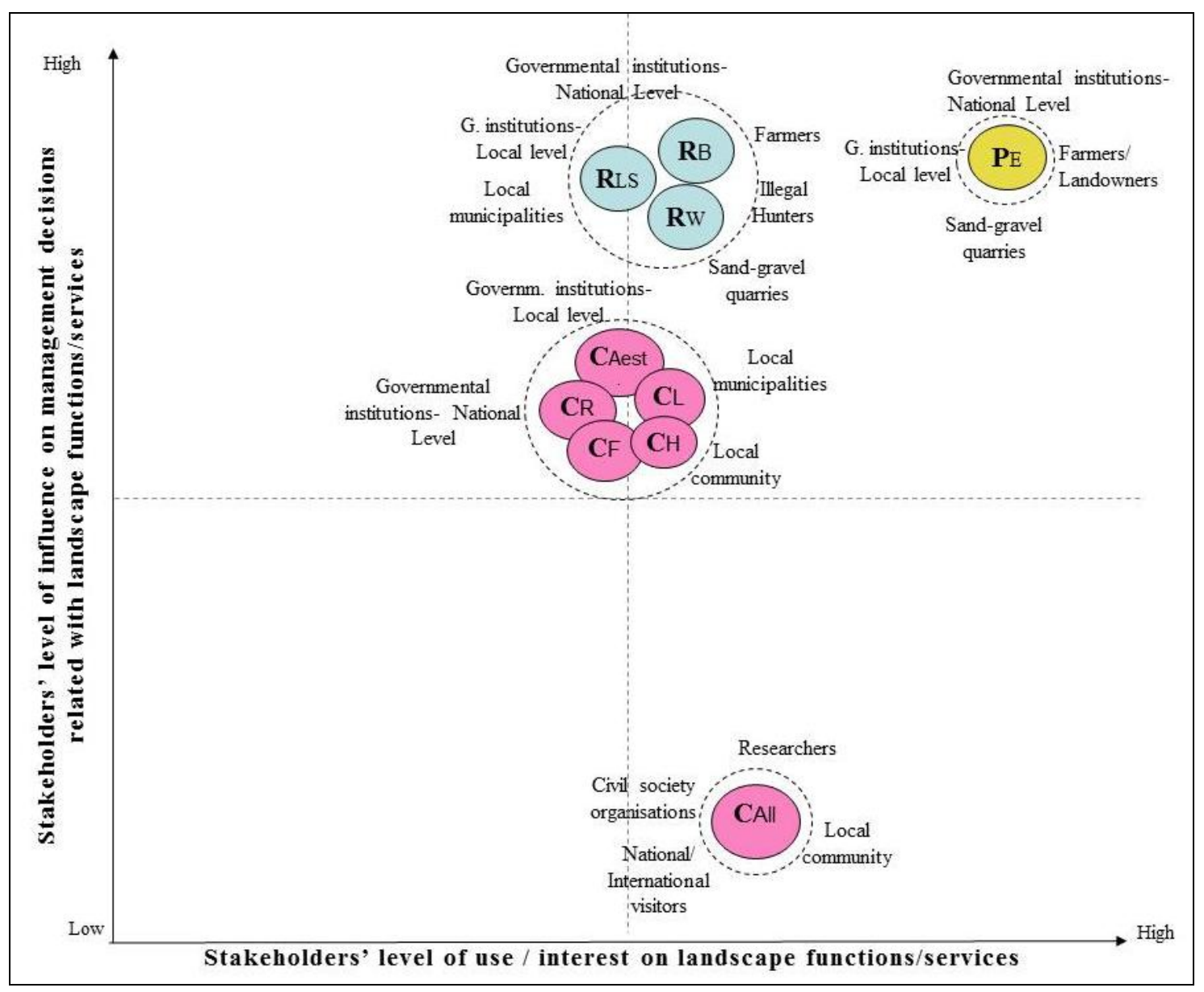

Figure 3. Stakeholder levels of use/interest and influence on management decisions concerning the landscape functions and services of Ekşisu Wetlands

One of the root causes of the problems identified in the study area is the lack of a wetland management plan. All of the above-mentioned factors such as over-grazing, drainage control and agricultural land expansion, abstraction of sand-gravel from the river bed and environmental pollutions and related degradation and degradation risks in the area as well as the lack of will to use the available legislative and administrative mechanisms directly and indirectly affect landscape characteristics, and as such, the landscape functions of Ekşisu Wetlands. Due to the negative effects on the study area's bioecological and physical characteristics associated with provisioning services, the regulation functions of the area are threatened. In addition, due to the interlinked relationships between landscape characteristics and functions, the socioeconomic and cultural characteristics of Ekşisu Wetlands (the ability to perform at capacity to fulfill its provisioning and cultural functions in the future) are at risk due to the threats to its bioecological characteristics.

\section{Landscape values assigned to Ekşisu Wetlands}

Among the 12 landscape values examined, future value was considered the most important (highest value score: 1475) by the area's stakeholders. Namely, heritage (1230), biodiversity (1145), and learning (1060) benefits are the next important values 
in the area. In contrast, spiritual (520) and therapeutic (630) values were the least important (lowest value scores) to the stakeholders (Figure 4). The stakeholders assigned importance to more than one place per landscape service, but more locations were marked for aesthetic and economic values than all the other landscape values that were investigated in the area.

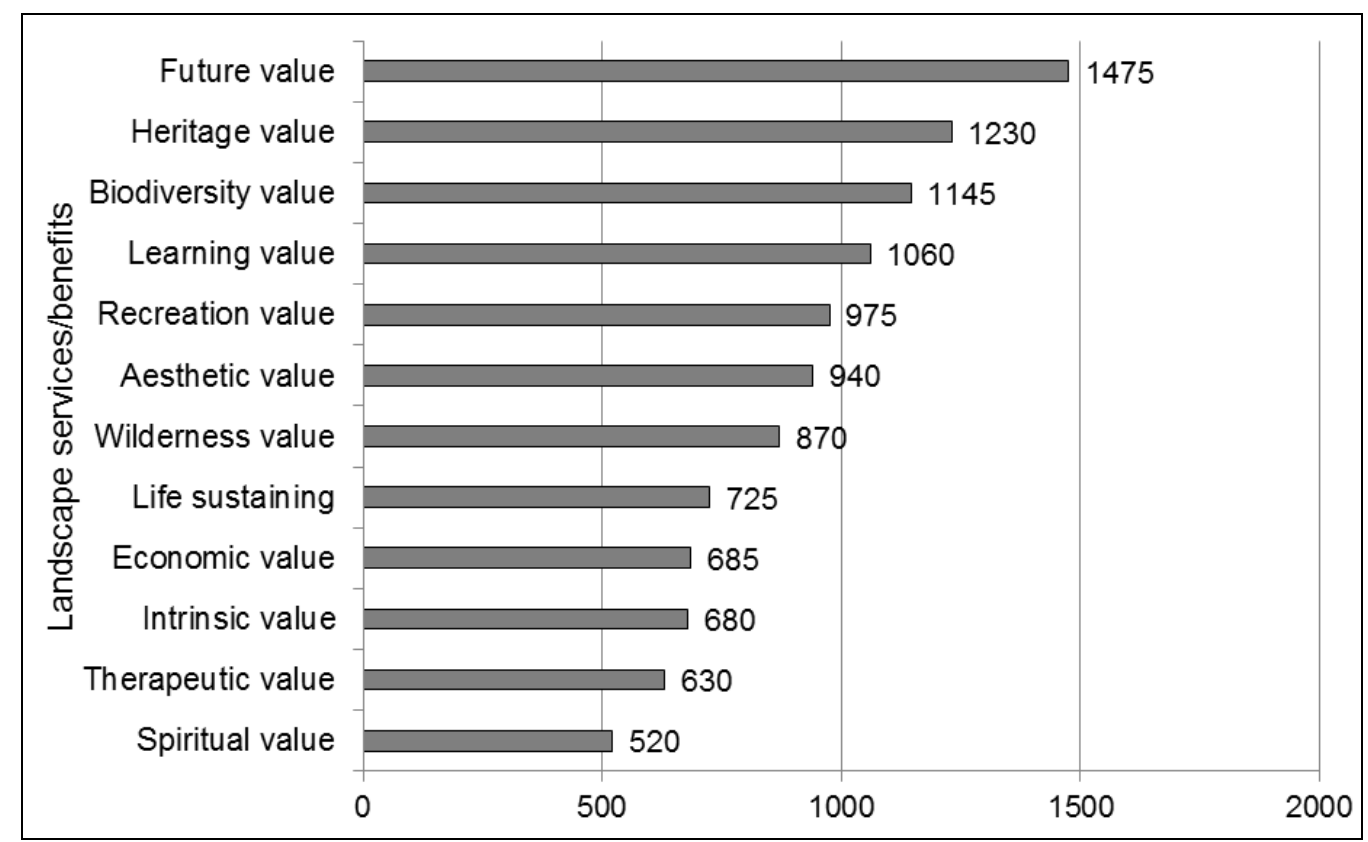

Figure 4. Landscape value scores for Ekşisu Wetlands

The area Ekşisu Park in the area that was designated for recreational purposes received high scores for all landscape values, except future and heritage values. The Altıntepe Archeological Site had the highest heritage (720) and future (720) value scores. Accordingly, Ekşisu Park and the Altıntepe Archeological Site were considered hotspots that are defined as the clusters of high values (Fagerholm and Niina Käyhkö, 2009) and areas that have functional diversity (Lavorel et al., 2010) because they provide multiple functions and benefits to the stakeholders. In addition, the Ekşisu Thermal Spring location was determined as the second important area for therapeutic benefits with the high therapeutic value score (225) after Ekşisu Park (370).

Ekşisu Wetlands landscape value mapping (based on stakeholder value scores) is shown in Figures 5a-5c. Locations with high scores for aesthetic value were higher in altitude than other areas and have an open view, along the banks of the Euphrates River, and Ekşisu marshes. These areas were also easier to access than other areas. Based on the observation of wetland birds, plants, and wild animals, the marshy area close to Ekşisu Park and Saztepe Archeological Site, and remote regions on the ridges of the Keşiş Mountains had high scores for biodiversity value. Areas with economic value were concentrated near rural settlements and agricultural areas, but also included locales with natural and cultural resources with the potential to generate tourism, including Ekşisu Thermal Spring, Ekşisu Park, and Altıntepe Archeological Site (Figure 5a). 


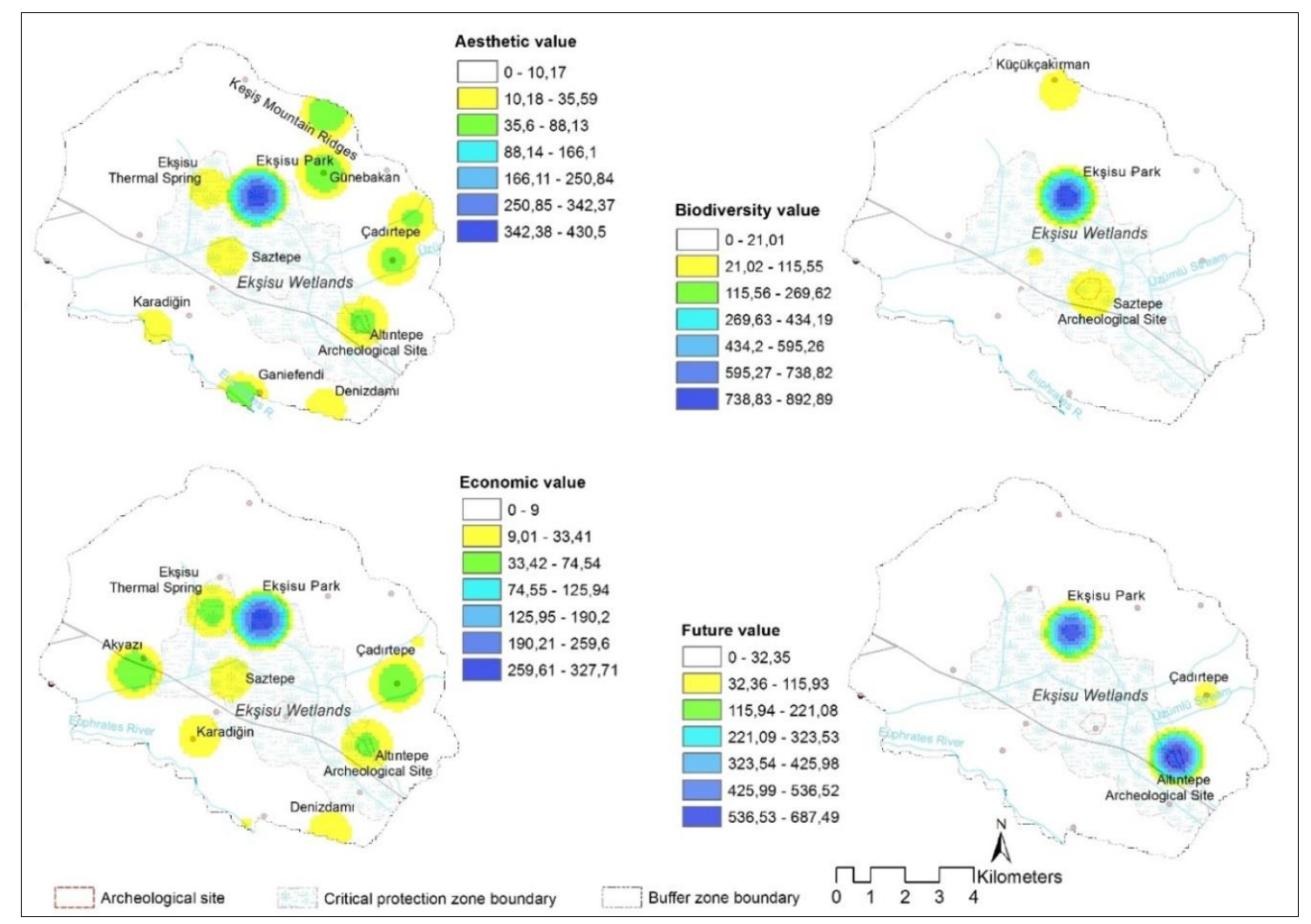

Figure 5a. Landscape value mapping for Ekşisu Wetlands

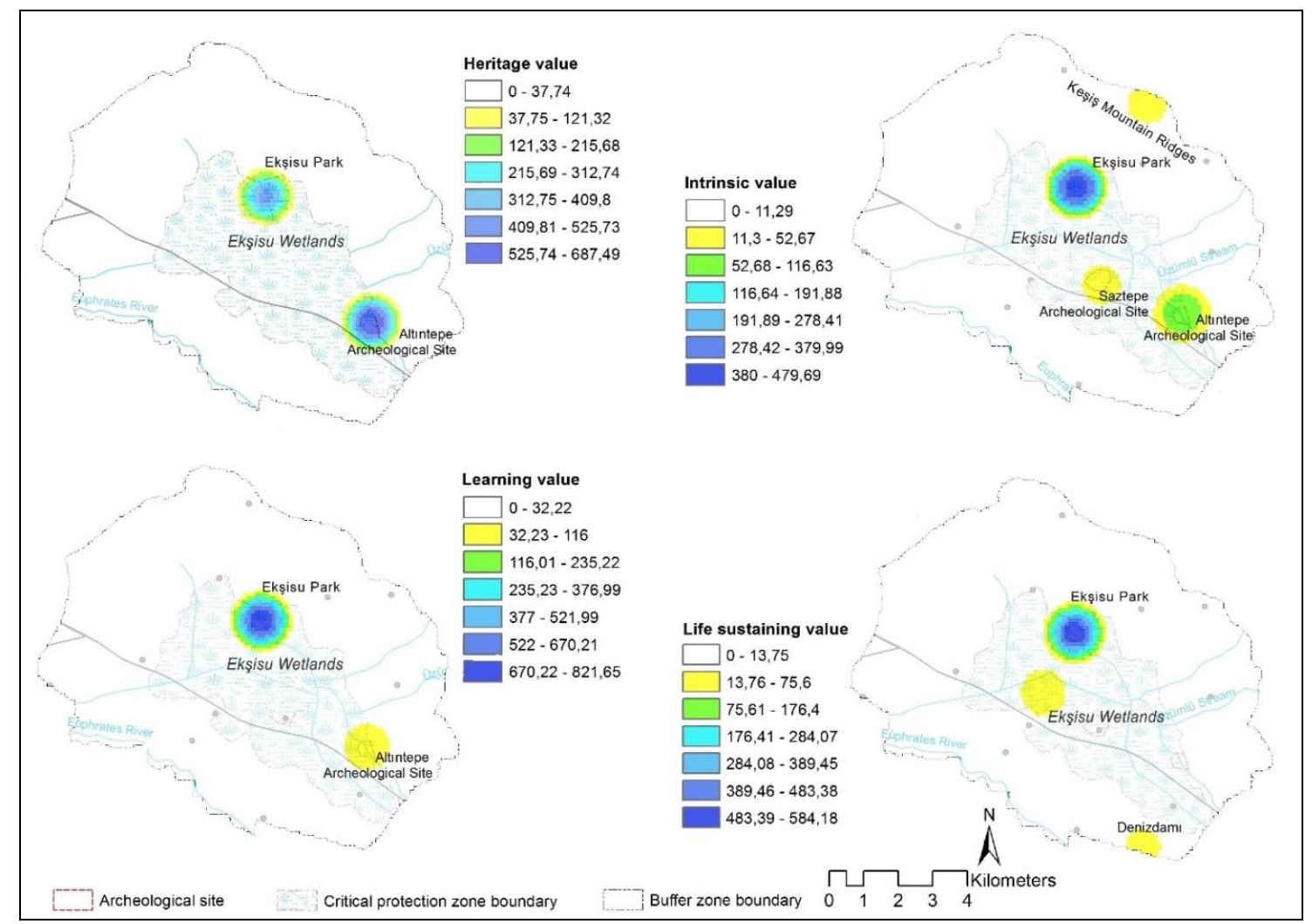

Figure 5b. Landscape value mapping for Ekşisu Wetlands

APPLIED ECOLOGY AND ENVIRONMENTAL RESEARCH 16(1):199-223. http://www.aloki.hu • ISSN 15891623 (Print) • ISSN 17850037 (Online) DOI: http://dx.doi.org/10.15666/aeer/1601_199223 (c) 2018, ALÖKI Kft., Budapest, Hungary 
One of the least important landscape values, which followed therapeutic and spiritual values, was intrinsic value. Locations with intrinsic value were Ekşisu Park and ridges of the Keşiş Mountains, and locations with cultural heritage, such as Altıntepe and Saztepe archeological sites. Learning value was the fourth most important value, though there were few such locations rated by the stakeholders. The high learning value scores for Ekşisu Park and the Altıntepe Archeological Site are indicative of their importance for cultural purposes and environmental knowledge and research. The high life sustaining value scores for such places as the banks of the Euphrates River, Üzümlü Stream, and the lake near Ekşisu Park indicate the importance to the stakeholders of water for ecological cycles (Figure $5 b$ ).

Locations that had high scores for recreation value were those the stakeholders enjoyed via use of recreational facilities, and because of historical, aesthetic, and wilderness value. Landscape value mapping showed that spiritual value was the least important value for the stakeholders in the area of Ekşisu Park and an old grave of a religious person in Çadırtepe Village. The next least important value was therapeutic value, which was mostly associated with the Ekşisu Thermal Spring facilities and Ekşisu Park. The wilderness value score was 625 for Ekşisu Park and the surrounding marshy area, and the ridges of the Keşiş Mountains, where the ecosystem is completely natural and wild animals can be observed (Figure 5c).

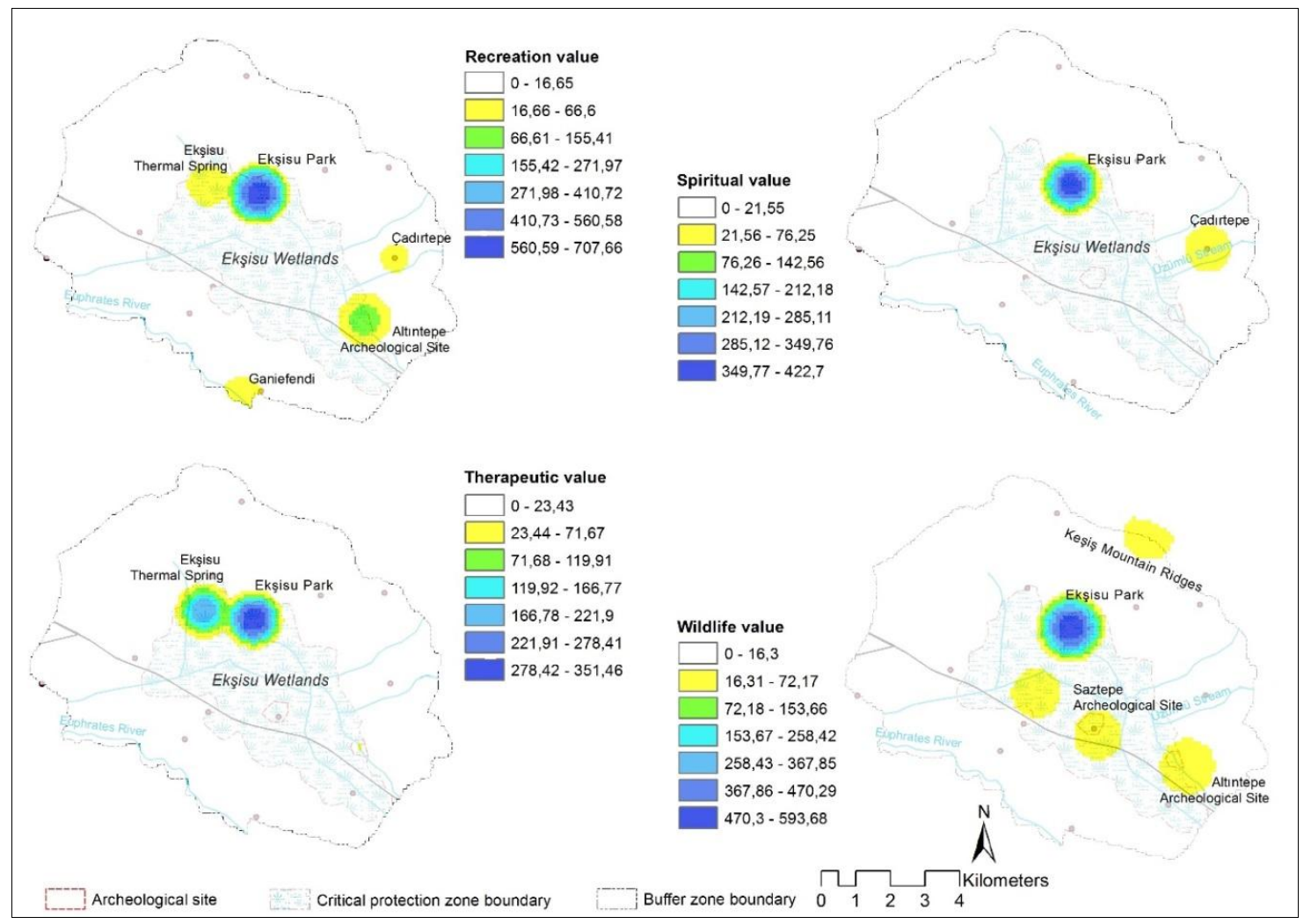

Figure 5c. Landscape value mapping for Ekşisu Wetlands

\section{Associations between landscape values and multifunctionality}

The 12 landscape values were measured in 16 locations within the study area and rendered as a $12 \times 16$ matrix using IBM SPSS statistics for Windows v.24.0. Factor 
analysis via PCA, following factor rotation, showed that the measured landscape values had a 2 -factor structure, which means there are 2 sets of associated landscape serviceslandscape service bundles that are linked to Ekşisu Wetlands. The structure of the determined factors with an eigen value $>1$ are shown in the scree plot and the component plot in rotated space (KMO measure of sampling adequacy $=0.794$ and Bartlett's test of sphericity $=502.599 ; \mathrm{df}=66 ; \mathrm{P}<0.000$ ) (Figure 6). Factor analysis results showed that the 2 factors explain $96 \%$ of the total variance; 1 factor explained $72 \%$ and 1 factor explained $25 \%$ of the variance. It was observed that the commonalities of the variables of those 2 factors ranged from 0.767 to 0.999 .
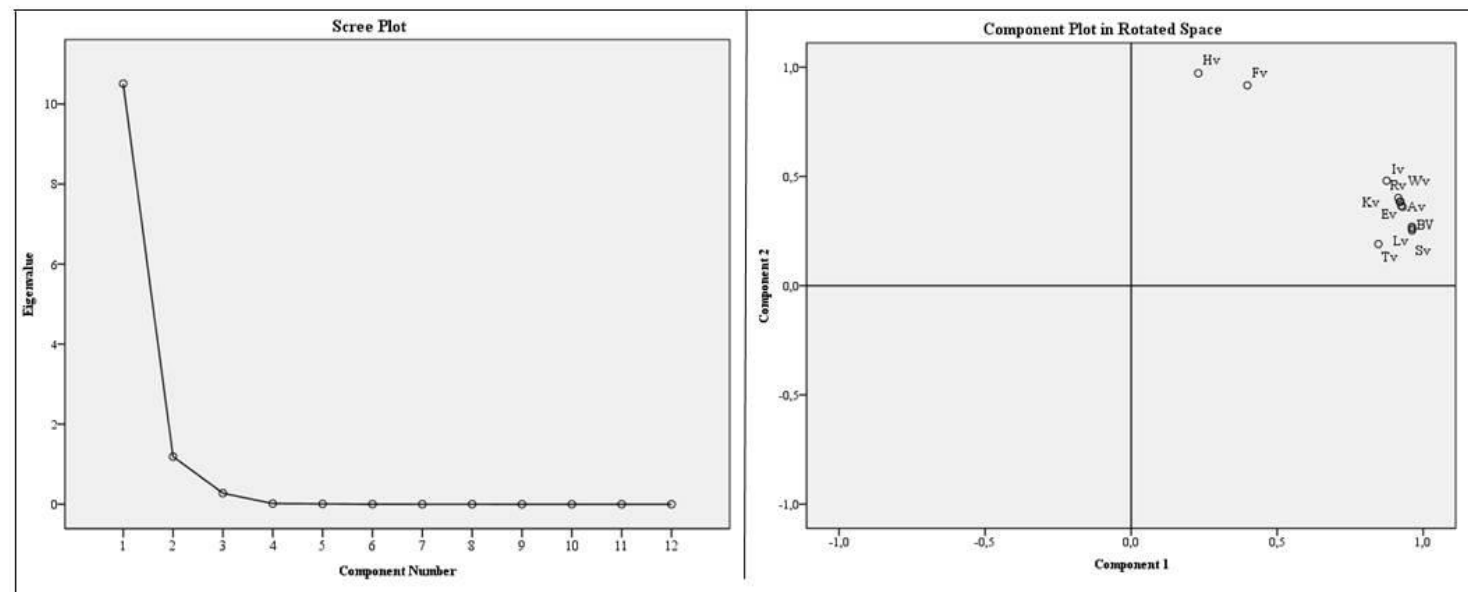

Av: Aesthetic Value Bv: Biodiversity Value Ev: Economic Value Fv. Future Value Hv: Heritage Value Iv: Intrinsic Value Kv:Knowledge Value Lv: Life Sustaining V. Rv: Recreation Value Sv:Spiritual Value Tv:Therapeutic Value Wv:Wilderness Value

Figure 6. Scree plot with eigen values based on PCA and factor analysis

The first factor included 10 landscape values- life sustaining, biodiversity, spiritual, aesthetic, learning, wilderness, recreation, economic, intrinsic, therapeutic- that are supplied by the landscape via actual (direct) and passive (indirect) use. Based on Hein et al. (2006), this factor was labeled Use and Non-Use Landscape Values (the first landscape service bundle [F1]). The second factor included heritage and future values, which are associated with the stakeholders' wish that future generations will benefit from Ekşisu Wetlands. This second factor was labeled Option Landscape Values (the second landscape service bundle [F2]). The factor loadings for the value items are given in Table 3.

The results of one-way ANOVA analysis of the links between the primary LULC types in the study area and landscape values performed to define the multifunctionality of the area showed that the importance assigned to the landscape value variables by the stakeholders for the F1 factor differed according to LULC categories $[\mathrm{F}(2-13)=5.377$, $\mathrm{P}<0.05]$. Post-hoc comparison using Tukey's HSD test showed that the mean factor score for Wetlands $(\bar{x}=1.7082)$ was significantly high than the natural grasslands $(\bar{x}=-$ $0.1194)$ and agriculture $(\bar{x}=-0.3133)$ type between LULC categories in F1's Factor scores (Tables 4 and 5). 
Table 3. Variable loadings for landscape services based on PCA

\begin{tabular}{llll}
\hline Landscape service variables & Use and Non-Use Values & Option Values (F2) & Commonalitie \\
\hline Life sustaining value & 0.956 & & 0.986 \\
Biodiversity value & 0.956 & 0.984 \\
Spiritual value & 0.950 & & 0.976 \\
Aesthetic value & 0.919 & 0.945 \\
Learning value & 0.918 & 0.995 \\
Wilderness value & 0.916 & 0.980 \\
Recreation value & 0.914 & & 0.996 \\
Economic value & 0.906 & & 0.932 \\
Intrinsic value & 0.865 & 0.971 & 0.991 \\
Therapeutic value & 0.846 & 0.916 & 0.767 \\
\hline Heritage value & & 1.16 & 0.999 \\
Future value & & 24.6 & 0.999 \\
\hline Eigenvalues & 10.38 & 96.2 \\
\hline Variance explained $(\%)$ & 71.6 & & \\
\hline
\end{tabular}

Table 4. Differences in mean landscape value scores for F1 according to LULC categories, based on one-way ANOVA

\begin{tabular}{|c|c|c|c|c|c|c|c|}
\hline Variable & LULC categories & $\mathbf{n}$ & Mean & sd & df & $\mathbf{F}$ & $\mathbf{P}$ \\
\hline \multirow{3}{*}{$\begin{array}{l}\text { Use and Non-Use } \\
\text { Landscape Values } \\
\text { (F1) }\end{array}$} & Wetlands & 2 & $1.7082^{\mathrm{a}}$ & 2.65 & \multirow{3}{*}{$2-13$} & \multirow{3}{*}{5.377} & \multirow{3}{*}{0.020} \\
\hline & Natural grassland & 5 & $-0.1194^{b}$ & 0.17 & & & \\
\hline & Agricultural areas & 9 & $-0.3133^{b}$ & 0.36 & & & \\
\hline
\end{tabular}

$\overline{\mathrm{a}, \mathrm{b}}$ The most important groups according to Tukey's test.

Table 5. Mean landscape value scores for LULC categories based on one-way ANOVA

\begin{tabular}{llllll}
\hline The Source of Change & Sum of Squares & df & Mean Square & F & P \\
\hline Between Groups & 6.791 & 2 & 3.395 & 5.377 & 0.020 \\
Within Groups & 8.209 & 13 & 0.631 & & \\
Total & 15.000 & 15 & & & \\
\hline
\end{tabular}

Additionally, the findings indicated that there was a non-significant effect of LULC type on the Option Values factor [F (2-13) $=0.482, \mathrm{P}>0.05]$. 


\section{Conflicting landscape services and stakeholders}

Data obtained via problem and stakeholder analyses, landscape value mapping, and LULC categories showed that 2 primary conflicts were generated by competing uses of the landscape functions and services in the drainage basin of Ekşisu Wetlands:

- Conflict between the nature conservation and agriculture sectors due to, the hydrologic regime employed, and degradation of habitats;

- Conflict between the stakeholders over provisioning, regulatory, and cultural services due to a high level of pressure on regulatory and cultural services resulting from the destructive effects of provisioning services (e.g. irrigation, drainage control for expand agricultural land, over grazing, sand and gravel quarrying).

Accordingly, local government institutions with primary responsibility for nature conservation are in conflict with farmers/landowners, illegal hunters, the local branch of State Water Affairs, and sand and gravel quarrying firms (Figure 7). Moreover, local communities are in conflict with local municipalities due to the lack of services and infrastructure necessary to benefit from the cultural functions of Ekşisu Wetlands.

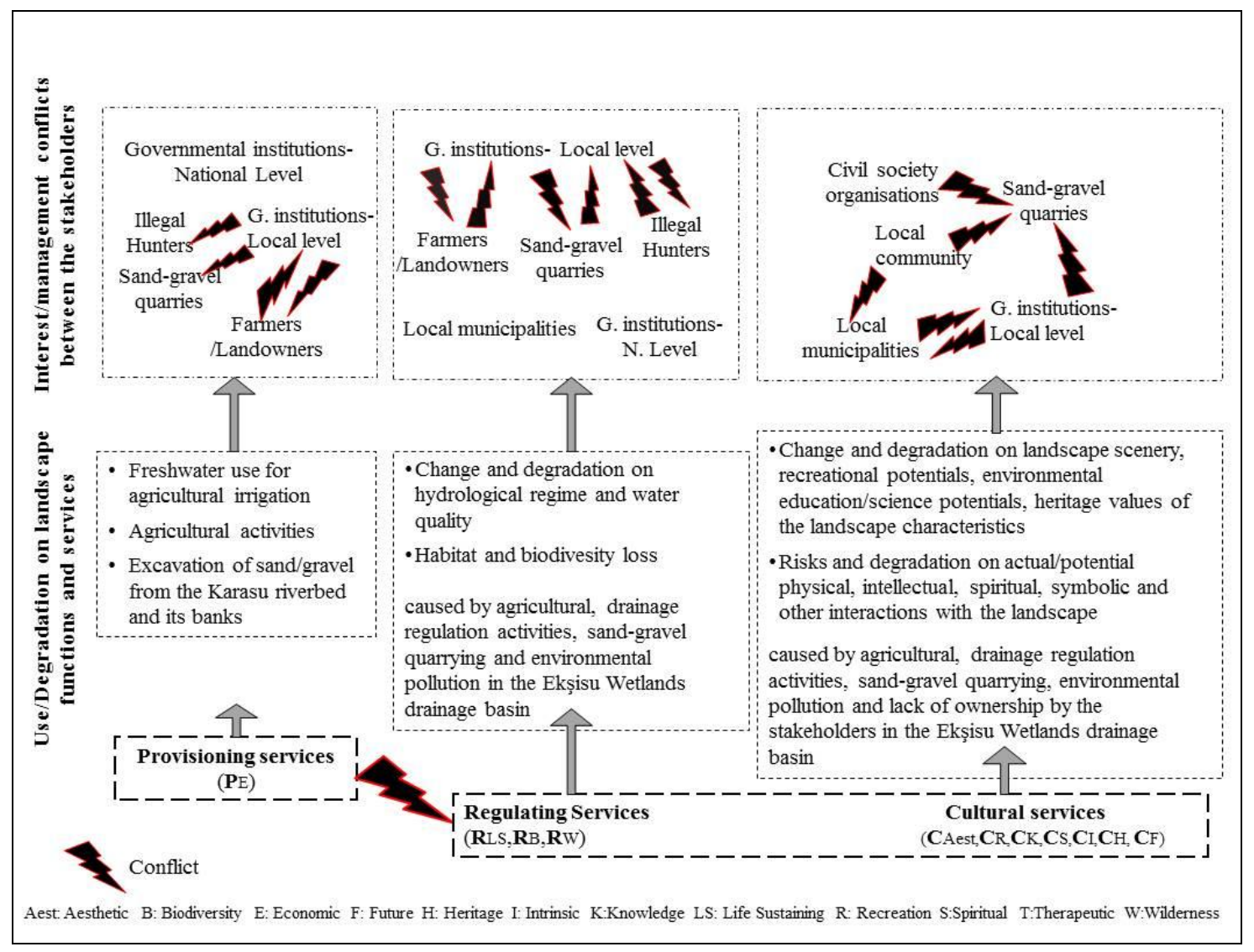

Figure 7. Use/interest and management conflicts between stakeholders concerning Ekşisu Wetlands' landscape services

\section{Discussion}

The present study analyzed the social and spatial dimensions of Ekşisu Wetlands, as well as their interactions, in an effort to identify the links in the Ekşisu Wetlands system 
in order to inform the collaborative landscape planning process for the wetlands. The results are presented as stakeholder interest/influence diagrams, value maps, conflict diagrams, and statistical figures. The findings show that there are strong associations between the Ekşisu Wetlands' landscape services, stakeholders, and LULC categories.

The present study's problem analysis show that Ekşisu Wetlands is under pressure from and the natural hydrological regime, habitat functions and cultural landscape service potentials are strongly negatively affected and degraded by various human activities. Agriculture, water diversion and drainage, and sand-gravel quarrying, lack of awareness of the wetlands' benefits, and lack of cooperation between stakeholders are some of the major factors that pose the greatest threat to Ekşisu Wetlands. Based on the poor state of the vegetation observed in the study area and surrounding mountains, soil erosion is another factor that threatens the area. Over grazing, clearance of natural vegetation cover, lack of enforcement of laws designed to protect pasture land, and alterations in drainage control hydrology to increase the amount of land suitable for agriculture have damaged the wetlands' plant and bird species populations and habitats.

In terms of landscape values, the present study area's stakeholders gave higher scores to cultural and regulation values than provisioning values, and considered the cultural and regulation value of the study area to be important for future generations. The Ekşisu Park area was identified as one of the few hotspots in the study area, with the maximum score for all landscape values, except heritage value and future value. The Altintepe Archeological Site was identified as the hotspot for heritage and future values as it is an archeological site with Bronze Age (B.C. 3200-1900), Urartu (B.C. 900-650), Byzantine (B.C. 74- A.D.629) ruins that the stakeholders want to exist for future generations. Value mapping analysis shows that the stakeholders consider multiple locations valuable because they provide benefits to daily life, including aesthetic, economic, and recreation value, due to Ekşisu Wetlands' material (tangible) elements and capacities.

As reported in earlier studies on landscape values (Beverly et al., 2008; Kaplan et al., 1998), the visual features of the landscape and its recreational facilities are of value to the Ekşisu Wetlands stakeholders, indicating that the value assigned to the landscape services by the stakeholders and their perceptions of landscape importance based on usage (land use) and attractive landscapes characterized by natural and cultural landscape elements, and land cover have a positive effect on their relationship with the landscape. These findings suggest that the stakeholders, including local municipalities responsible for the management of Ekşisu Wetlands, should consider the importance of the development of facilities and activities that strengthen the connection between the stakeholders and the study area.

The low intrinsic, therapeutic and spiritual value score might have been related to the difficulty assigning importance to such intangible landscape values or very low-level landscape-related intangible meaning to the stakeholders. As an example; the low score for spiritual value might have been due to the absence of or minimal spiritual interactions with nature and with the study area among the stakeholders. The low score for therapeutic value might be indicative of the fact that the stakeholders derived little physical and psychological healing which might have been related to a lack of needed facilities at Ekşisu Wetlands, with the exception of a newly established Ekşisu Thermal Spring facility. The low intrinsic value score for Ekşisu Wetlands might also be related to a low level of knowledge and/or interest in ecological and social issues related to the area, both locally and nationally; if true, this indicates that educational programs 
designed to increase such knowledge and interest among the stakeholders should be incorporated into future collaborative planning processes for the area.

Employing PCA and factor analysis facilitated identification of the 12 landscape values in 2 general categories that are consistent with ecosystem service value type categorization, and wetland functions and value types (Hein et al., 2006). The results of the analysis also confirm the interlinkage and multifunctionality of Ekşisu Wetlands with 2 sets of landscape value bundles (F1 and F2). The factor analysis results show that there are strong positive associations between the use and non-use values of Ekşisu Wetlands that might be a result of the stakeholders' valuation of particular areas not only for a specific benefit, but also for different benefits, as reported earlier (Zhu et al., 2010). The observed positive associations between the use and non-use values might also have resulted from the synergy between landscape values, which if true, would require additional research and landscape services trade-off analysis to better inform actions designed to protect the multifunctionality of the study area. The observation of significant associations between landscape values and LULC types in Ekşisu Wetlands also confirm the existence of interlinkages between landscape functions and LULC types, as reported by Plieninger et al. (2013).

Analysis of the spatial associations between the landscape values show that the associated services-use and non-use landscape value bundle-also spatially co-occur in specific LULC types in Ekşisu Wetlands. One-way ANOVA of landscape values according to LULC type indicate that wetlands are of greater importance to the Ekşisu Wetlands stakeholders than expected based on the proportion of the study area categorized according to LULC agricultural land and grasslands. This result is similar to that reported by Kaltenborn and Bjerke (2002) and Brown et al. (2012), who observed that landscapes with lake elements were perceived to be more attractive than flat and open agricultural areas. Their findings and those of the present study indicate that LULC type affects stakeholder perception and valuation of landscape services.

\section{Relevance for collaborative landscape management}

Recent natural resource management and landscape policies and related research in developed countries have focused on landscape multifunctionality. In accordance with the need and demand for participatory planning approaches, the multifunctionality perspective requires that the landscape planning process considers and includes all relevant landscape stakeholders, as well as takes into consideration landscape functions and services to ensure sustainable landscape development (Albert et al., 2014; Sitas et al., 2014).

According to problem and stakeholder analysis, and conflict analysis findings in the present study, Ekşisu Wetlands is under pressure, has been damaged, and suffers due to conflicts between its stakeholders. The pressures and problems that threaten its landscape characteristics-and as such, its multifunctionality and landscape services-are a result of competing demands, unequal power relationships, and policy makers' lack of understanding of local stakeholders' relationship with the landscape. Worldwide, a wide range of landscapes are negatively impacted by similar issues and problems (MEA, 2005; Pinto-Correia et al., 2006; Selman, 2009; Willemen et al., 2010 and Hermann et al., 2011). In terms of wetlands damage and loss, Ekşisu Wetlands is similar to many other wetlands throughout the world, based on reports by Turner et al. (2000), Dixon and Wood (2003), Finlayson et al. (2005) and de Groot et al. (2006); therefore, the 
present findings indicate that the responsible national and local government bodies must create an Ekşisu Wetlands management plan in collaboration with all stakeholders.

As they can help delineate a landscape's various stakeholders' views and evaluations of a landscape, which are often ignored by conventional landscape research methodologies (Mander et al., 2007), the landscape values concept and landscape value mapping process are instrumental to collaborative landscape planning, and can inform the decision-making processes. Accordingly, in the present study a workshop-based landscape value mapping process was used to determine the Ekşisu Wetlands' stakeholders' opinions and evaluations of the landscape's benefits. As reported by Brown (2006), in addition to other communication tools that can be used with landscape stakeholders, landscape value mapping and the data it generates provide locationspecific information that can be used by all relevant stakeholders for planning the development of landscapes. The present findings show that sociocultural valuation via landscape value mapping can be used to assess the perceived benefits of simultaneously performed multiple functions of a landscape, as well as for sociocultural assessment of wetlands.

Landscape value mapping can also help planners and decision makers formulate priorities and alternatives during the landscape planning process as stated by Brown (2005), Daily et al. (2009), Raymond et al. (2009) and Zhu et al. (2010), as well as during the management process; therefore, as reported by Soini (2001), Fagerholm et al. (2012), Brown and Donovan (2014), landscape value mapping remains a valuable method for landscape research and landscape planning. Yet, as observed during the mapping workshop performed during the present study, the value of the data obtained is limited due to the limited number of stakeholders that participated, their limited knowledge about the area, and their limited ability to express their opinions and perceptions about the study area's intangible values and other landscape values.

According to the present study's conflict analysis findings, the stakeholders' benefits from provisioning services result conflicts for the sustainability and protection of regulation and cultural landscape services, Stakeholders are in conflict over many wetland landscapes worldwide (Eppink et al., 2004; Hansson et al., 2005; Hein et al., 2006; Posthumus et al., 2010) and similar dynamics are occurring in the context of Ekşisu Wetland; therefore, as a multifunctional landscape, the various functions of and benefits provided by Ekşisu Wetlands are under threat.

The present study shows that problems related to sustainability of landscape functions, landscape values, and stakeholder conflicts are 3 concepts that can be used to form the basis of a collaborative planning and management processes that aim to preserve the multifunctionality of Ekşisu Wetlands. The stakeholders' shared values, which were identified via a collaborative process and can be used to inform the collaborative planning process for Ekşisu Wetlands, included heritage value, biological diversity value, future value, knowledge value, recreation value, and wilderness value. Accordingly, habitat protection and improvement, and protecting and improving the area's regulating and cultural functions were defined as priorities for the collaborative management of the area. According to stakeholder analysis findings, the stakeholders with the most power and those in conflict with each other must collaborate during the planning and management of the Ekşisu Wetlands, and those with little power and that not in conflict must be informed of the process.

According to the power of influence in decision making processes for the area, national and local governmental institutions, together with local municipalities, are the 
stakeholders best able to protect and improve the multifunctionality of Ekşisu Wetlands. Improvement of the natural hydrological cycle and erosion control measures, and enforcement of all laws regarding the protection of pasture land and biodiversity in the study area should be considered primary goals of the collaborative planning process. Farmers/landowners, hunters, and sand-gravel quarry firms, together with civil society organizations and representatives of the local community, must be encouraged to participate and/or support the activities of the Ekşisu Wetlands' other more powerful stakeholders. Participatory decision-making tools and methods, including facilitation, negotiation, conflict management, and wetland management, should be the focus of capacity building activities for the stakeholders both in the national and local level.

\section{Conclusion}

As a result of their multifunctionality, landscape degradation and stakeholder conflicts on wetland landscapes generally arise due to the competing interests of the multiple stakeholders. Turkey is as rich in terms of its wetlands, their multifuncionality and conflicts between the wetlands' stakeholders as it is poor in terms of their participatory planning and management. Therefore, Turkey has to give emphasis to protect the multifunctionality of her wetlands via identifying and understanding the importance and value of the benefits provided by these landscapes to local communities and stakeholders, as well as the stakeholders' conflicting interests. This case study on Ekşisu Wetlands emphases the need for understanding the social and spatial dimensions of wetlands, as well as their interactions, in an effort to identify the links in wetland systems so as to inform a collaborative planning process aimed at protecting the multifunctionality of these critical landscapes.

Although assessing multifunctionality is more easily addressed on a small wetland landscape, this case study has demonstrated the pressures and degradations through provisioning services that result conflicts for the sustainability and protection of regulation and cultural landscape services that are also faced in many wider wetland landscapes. Sustainability of landscape functions, improving the perceived and experienced benefits of local people, and conflict resolution between its stakeholders are the main concepts that can be used to form the basis of a collaborative planning and management processes that aim to preserve the multifunctionality of wetlands and other landscapes. Although the current and dominating top-down planning culture in the country and in the case area, national and local governmental institutions, together with local municipalities, are the stakeholders best able to protect the multifunctionality of Ekşisu Wetlands.

It is clear that the collaborative landscape planning process can play an important role in protecting the multiple functions of today's contested landscapes-if various stakeholders with multiple interests can commit to a shared vision and common goals. As such, common values and conflicts related to landscapes need to be identified via consensus and a negotiation-based joint working processes in order to foster shared responsibility for and assignment of value to the multidimensional character of landscapes.

While landscape value mapping methodology enables to identify various perceived benefits of and shared values for the landscape it is subject to some limitations in mapping the intangible landscape values such as spiritual and intrinsic. Additional work with qualitative methods can help to minimize these limitations of landscape value 
mapping. Employing PCA and factor analysis has demonstrated the interlinkages between landscape capacities and experienced benefits. Therefore, these analyses also enabled to understand the Ekşisu's multifunctionality. However, further research is needed on the synergies and trade-offs between the use and non-use landscape values and on the socio-cultural landscape characteristics to better inform collaborative actions designed to protect the multifunctionality of landscapes.

Acknowledgements. This study was based in part on a project supported by The Scientific and Technological Research Council of Turkey (TUBITAK), CAYDAG Committee (project no. 110Y285).

\section{REFERENCES}

[1] Akkan, E. (1964): Erzincan Ovası ve Çevresinin Jeomorfolojisi (in Turkish), Yayın No: 153. - Ankara Üniversitesi Basımevi, Ankara.

[2] Akyıldız, D., Kılıç, D.T., (2006): Ekşisu Sazlığı. - In: Eken, G., Bozdoğan, M., İsfendiyaroğlu, S., Kılıç, D.T., Lise, Y. (eds.) Türkiye'nin Doğal Alanları (Cilt II): 276277. (in Turkish), Doğa Derneği, Türkiye, Ankara.

[3] Albert, C., Aronson, J., Fürst, C., Opdam, P. (2014): Integrating ecosystem services in landscape planning: requirements, approaches, and impacts. - Landscape Ecology (29)8:1277-1285.

[4] Alessa, L., Kliskey, A., Brown, G. (2008): Social-ecological hotspots mapping: A spatial approach for identifying coupled social-ecological space. - Landscape and Urban Planning 85(1): 27-39.

[5] Anonymous (2005): Erzincan İl Özel İdaresi 2006-2008 Stratejik Yatırım Planı (in Turkish), connection on 15 March 2014. URL:http://www.erzincanilozelidaresi.gov.tr/.

[6] Anonymous (2010): Erzincan İli Stratejik Planı (2010-2014) (in Turkish), Erzincan Valiliği. connection on 15 April 2014. URL: http://www.erzincanilozelidaresi.gov.tr/.

[7] Anonymous (2012): National Land Cover (Erzincan). Land Monitoring System. - T.R. Ministry of Forestry and Waterworks. connection on 20 June 2014. URL:http://aris.ormansu.gov.tr/crn/.

[8] Anonymous (2014): Erzincan İli 2013 Yılı Çevre Durum Raporu (in Turkish). - ÇED, İzin ve Denetim Şube Müdürlügü. T.C. Erzincan Valiliği Çevre ve Şehircilik İl Müdürlüğü, Çevre ve Şehircilik Bakanlığı, Erzincan.

[9] Anonymous. (2017): Official statistics, connection on 15 February 2017. URL: https://www.mgm.gov.tr/veridegerlendirme/il-ve-ilceler-istatistik.aspx?m=ERZINCAN

[10] Anonymous (2017): Stakeholder Analysis, Project Management, templates and advice connection on 22 November 2017. URL: https://www.stakeholdermap.com/stakeholderdefinition.html\#what-is-a-stakeholder

[11] Arnstein, S. R (1969): A ladder of citizen participation. - Journal of the American Planning Association 35(4):216-224.

[12] Aslay, M. Kandemir, A. (2009): The study of conservation of sonchus erzincanicus matthews (asteraceae) Turkey (in turkish). - Erzincan Üniversitesi - Fen Bilimleri Enstitüsü Dergisi 2(1):1-15.

[13] Baylan, E. (2012): Collaborative Landscape Planning for Natural Resource Management: Karasu River Case, Ph.D. Thesis. - Department of Landscape Architecture Graduate School of Applied Sciences of Ankara University, Ankara. (in Turkish).

[14] Beverly, J., Uto, K., Wilkes, J., Bothwell, P. (2008): Assessing spatial attributes of forest landscape values: An internet-based participatory mapping approach.- Canadian Journal of Forest Research 38(2): 289-303.

[15] Bollinger, J., Kienast, F. (2010): Landscape functions in a changing environment.Landscape Online (22): 1-5. 
[16] Bollinger, J., Bättig, M., Gallati, J., Kläy, A., Stauffacher, M., Kienast, F. (2011): Landscape multifunctionality: A powerful concept to identify effects of environmental change. -Regional Environmental Change (11): 203-206.

[17] Brander, L.M., Florax, J.G.M., Vermaat, J.E. (2006): The empirics of wetland valuation: A comprehensive summary and meta-analysis of the literature.- Environmental and Resource Economics (33): 223-250.

[18] Brandt, J., Tress, B., Tress, G. (2000): Multifunctional Landscapes: Interdisciplinary Approaches to Landscape Research and Management: Conference material for the conference on "multifunctional landscapes", Centre for Landscape Research, Roskilde, $18-21$ October 2000.

[19] Brown, G. (2005): Mapping spatial attributes in survey research for natural resource management: Methods and applications.- Society and Natural Resources (18): 17 - 39.

[20] Brown, G. (2006): Mapping landscape values and development preferences: A method for tourism and residential development planning. - International Journal of Tourism Research 8(2): 101-113.

[21] Brown, G., Raymond, C. (2007): The relationship between place attachment and landscape values: Toward mapping place attachment.- Applied Geography (27): 89-111.

[22] Brown, G., \& Donovan, S. (2014). Measuring change in place values for environmental and natural resource planning using Public Participation GIS (PPGIS): results and challenges for longitudinal research. - Society \& Natural Resources 27(1): 36-54.

[23] Buchecker, M., Hunziker, M., Kienast, F. (2003): Participatory landscape development: overcoming social barriers to public involvement. - Landscape and Urban Planning 64 (1-2): 29-46.

[24] Carpenter, S. R., Bennett, E. M., Peterson, G. D. (2006): Scenarios for ecosystem services: An overview. - Ecology and Society 11(1): 29.

[25] Common International Classification of Ecosystem Services (CICES), connection on 05 December 2016, URL: http://biodiversity.europa.eu/maes/common-internationalclassification-of-ecosystem-services-cices-classification-version-4.3.

[26] Curebal, I., Efe, R., Soykan, A., Sonmez, S. (2015): Impacts of anthropogenic factors on land degradation during the anthropocene in Turkey.- Journal of Environmental Biology (36) Special issue: $51-58$.

[27] Daily, G. C., Polasky, S., Goldstein, J., Kareiva, P. M., Mooney, H. A., Pejchar, L., Ricketts, T. H., Salzman, J., Shallenberger, R. (2009): Ecosystem services in decisionmaking: Time to deliver. - Frontiers in Ecology and the Environment 7(1): 21-28.

[28] de Groot, R. (2006): Function-analysis and valuation as a tool to assess land use conflicts in planning for sustainable: Multi-functional landscapes.- Landscape and Urban Planning (75):175-186.

[29] de Groot, R.S., Stuip, M.A.M., Finlayson, C.M., Davidson, N. (2006): Valuing wetlands: Guidance for valuing the benefits derived from wetland ecosystem services, Ramsar Technical Report No. 3/CBD Technical Series No. 27, Ramsar Convention Secretariat, Gland, Switzerland \& Secretariat of the Convention on Biological Diversity, Montreal, Canada, connection on 15 December 2015. URL: https://www.cbd.int/doc/publications/cbd-ts-27.pdf.

[30] Dijkstra, A.M., Gutteling, J.M., Swart, J.A.A., Wieringa, N.F., van der Windt, H.J., Seydel, E.R. (2011): Public participation in genomics research in the Netherlands: Validating a measurement scale. - Public Understanding of Science 20(10):1-13.

[31] Dixon, A. B., Wood, A. P. (2003): Wetland cultivation and hydrological management in Eastern Africa: Matching community and hydrological needs through sustainable wetland use. - Natural Resources Forum27(2): 117-129.

[32] Doğan, S., Sevsay, S., Ayyıldız, N., Özbek, H. H., Dilkaraoğlu, S., Erman, O., Aksoy, H. (2015): The mite fauna of Ekşisu Marshes in Erzincan (Turkey). Turkish Journal of Zoology (39): 571-579. 
[33] Eppink, F.V, van den Bergh J.C.J.M., Rietveld, P. (2004): Modelling biodiversity and land use: Urban growth, agriculture and nature in a wetland area. - Ecological Economics (51): $201-216$.

[34] Fagerholm, N., Käyhkö, N. (2009): Participatory mapping and geographical patterns of the social landscape values of rural communities in Zanzibar, Tanzania.- Fennia (187): 43-60.

[35] Fagerholm, N., Käyhkö, N., Ndumbaro, F., Khamis, M. (2012): Community stakeholders' knowledge in landscape assessments-Mapping indicators for landscape services.- Ecological Indicators (18): 421-433.

[36] Ferreyra, C., Beard, P. (2007): Participatory evaluation of collaborative and integrated water management: Insights from the field. - Journal of Environmental Planning and Management 50(2):271-296

[37] Finlayson, C.M., D’Cruz, R., Davidson, N.C. (2005): Ecosystems and Human WellBeing: Wetlands and WaterWorld Resources Institute, Washington D.C., connection on 15 December 2015. URL: http://www. millenniumassessment.org/documents/document. 358.aspx.pdf.

[38] Fisher, B., Turner, R. K. (2008): Ecosystem services: Classification for valuation.Biological Conservation 141 (5): 1167-1169.

[39] Fry, G. (2001): Multifunctional landscapes - Towards transdisciplinary research.Landscape and Urban Planning (57): 159-168.

[40] Grimble, R., Wellard, K. (1997): Stakeholder methodologies in natural resource management: A review of concepts, contexts, experiences and opportunities. Agricultural Systems (55): 173-193.

[41] Haines-Young, R.H., Potschin, M.B. (2010): The links between biodiversity, ecosystem services and human well-being, - In: Raffaelli, D., Frid, C. (eds.) Ecosystem Ecology: a New Synthesis, Cambridge University Press, Cambridge.

[42] Hansson, L.-A., Brönmark, C., Anders Nilsson, P., Åbjörnsson, K. (2005): Conflicting demands on wetland ecosystem services: Nutrient retention, biodiversity or both? Freshwater Biology (50): 705-714.

[43] Hayli, S. (2002): Erzincan ovasında genel arazi kullanımı (in Turkish).- Firat Üniversitesi Sosyal Bilimler Dergisi 12 (1): 1-23.

[44] Healey, P. (2003): Collaborative planning in perspective.- Planning Theory 2(2):101-123.

[45] Hein, L., Koppen, K., Groot, R. S., Ireland, E. C. (2006): Spatial scales, stakeholders and the valuation of ecosystem services.- Ecological Economics 57(2): 209 - 228.

[46] Hermann, A., Schleifer, S., Wrbka, T. (2011): The concept of ecosystem services regarding landscape research: A review. - Living Reviews, Landscape Research 5 (1):137.

[47] Innes, J.E., Booher, D. E. (2010): Planning With Complexity: An Introduction To Collaborative Rationality For Public Policy. - Routledge Taylor \& Francis Group. London and New York.

[48] Johnson, N., Ravnborg, M.H., Westermann, O., Probst, K. (2002): User participation in watershed management and research. - Water Policy 3(6):507-520

[49] Kaltenborn, P. B., Bjerke T. (2002): Associations between landscape preferences and place attachment: A study In Søros, Southern Norway.- Landscape Research 27 (4): 381396.

[50] Karadeniz, N., Tir1l, A., Baylan, E. (2009): Wetland management in Turkey: problems, achievements and perspectives. - African Journal of Agricultural Research (4):1106-1119.

[51] Kaya, M. (2011): Erzincan iklim ve meteoroloji verileri (in Turkish). - Tesisat Mühendisliği (124): 34-42. 
[52] Kienast F., Bolliger J., de Groot R.S., Potschin M., Haines-Young R., Verburg P., Heller I. (2009): Assessing landscape functions at the continental scale: A methodological framework. - Environmental Management (44):1099-1120.

[53] Lavorel, S., K. Grigulis, P. Lamarque, M.-P. Colace, D. Garden, J. Girel, G. Pellet, and R. Douzet. (2010): Using plant functional traits to understand the landscape distribution of multiple ecosystem services. - Journal of Ecology (99): 135-147.

[54] Luz, F. (2000): Participatory landscape ecology: A basis for acceptance and implementation.- Landscape and Urban Planning 50 (1-3): 157-166.

[55] Mander, Ü., Helming, K., Wiggering, H. (2007): Multifunctional land use: meeting future demands for landscape goods and services. - In: Multifunctional Land Use, Springer, Berlin Heidelberg.

[56] Manzo, C. L., Perkins D. D. (2006): Finding common ground: The 1mportance of place attachment to community participation and planning. - Journal of Planning Literature (20): 335-350.

[57] Margerum, D. R. (2002): Collaborative planning building consensus and building: A distinct model for practice.- Journal of Planning Education and Research (21): 237-253.

[58] Mason, S., Rychard,S. (2005): Conflict Analysis Tools.- In: Swiss Agency for Development and Cooperation (ed): Conflict Prevention and Transformation Division (COPRET). Bern, Switzerland, connection on 15 December 2016. URL: http://www.isn.ethz.ch/Digital-Library/Publications/Detail/ ?id=15416 .

[59] Millennium Ecosystem Assessment (MEA). (2005): Ecosystems and Human Well-being: Synthesis. Island Press, Washington, DC, pp. 1-101. connection on 15 April 2015. URL: http://www.millenniumassessment.org/documents/ document.356.aspx.pdf.

[60] Mitsch, J. W., Gosselink, G. J. (2000): The value of wetlands: Importance of scale and landscape setting.- Ecological Economics 35 (1): 25-33.

[61] Mostert, E. (2003): The challenge of public participation. - Water Policy (5): 179-197.

[62] Nassauer, I. J. (1995): Culture and changing landscape structure.- Landscape Ecology 10 (4): 229-237.

[63] Naveh, Z. (2001): Ten major premises for a holistic conception of multifunctional landscapes. - Landscape and Urban Planning (57): 269-284.

[64] Oliveira, R., Dneboská, M. (2004): From landscape perception until public participation. how long is the way? - In: International Conference "From Landscape Knowledge to Landscaping Action,Bordeaux, France.

[65] Oñate, J. J., Peco, B. (2005): Policy impact on desertification: Stakeholders' perceptions in Southeast Spain. - Land Use Policy 22(2): 103-104.

[66] Overall, M. P. (2005): Toward a theory of collaboration for teachers and librarians. School Library Media Research (8), connection on 15 May 2011. URL: http://www.ala.org/ala/mgrps/divs/aasl/aaslpubsandjournals/slmrb/slmrcontents/ volume82005/theory.cfm.

[67] Pahl-Wostl, C., Craps, M., Dewulf, A., Mostert, E., Tàbara, D., Taillieu, T. (2007): Social learning and water resources management. - Ecology and Society 12(2): 5.

[68] Plieninger, T., Dijks, S., Oteros-Rozas, E. and Bieling, C. (2013): Assessing, mapping, and quantifying cultural ecosystem services at community level. - Land use policy (33): 118-129.

[69] Pinto-Correia, T., Gustavsson R., Pirnat J. (2006): Bridging the gap between centrally defined policies and local decisions- Towards more sensitive and creative rural landscape management. - Landscape Ecology (21): 333-346.

[70] Posthumus, H., Rouquette, J.R., Morris, J., Gowing, D.J.G., Hess, T.M. (2010): A framework for the assessment of ecosystem goods and services: A case study on lowland floodplains in England. - Ecological Economics 69 (7): 1510-1523.

[71] Potschin, M., Haines-Young, R. H. (2006): Rio + 10, sustainability science and landscape ecology. - Landscape and Urban Planning 75(3-4): 162-74. 
[72] Raymond, C. M., Bryan, B. A., MacDonald, D. H., Cast, A., Strathearn, S., Grandgirard, A., Kalivas,T. (2009): Mapping community values for natural capital and ecosystem services. - Ecological Economics 68(5):1301-1315.

[73] Kaplan, R., Kaplan, S., Ryan, R.(1998):With People in Mind: Design And Management of Everyday Nature. - Island Press, Washington

[74] Rolston, H., Coufal, J.(1991): A forest ethic and multi-value forest management. - Journal of Forestry 89(4):35-40.

[75] Rooney, J., Heuvel, N. (July 2004): Root Cause Analysis For Beginners. - Quality Progress 45-53.

[76] Sabatier, A.P., Focht, W., Lubell, M., Trachtenberg, Z., Vedlitz, A., Matlock, M. (2005): Swimming upstream: Collaborative approaches to watershed management. - Cambridge, MA: MIT Press, United States.

[77] Selin, S., Chevez, D. (1995): Developing a collaborative model for environmental planning and management.- Environmental Management (19)2:189-1995.

[78] Selman, P. (2004): Community participation in the planning and management of cultural landscapes.- Journal of Environmental Planning and Management 47(3): 365-392.

[79] Selman, P. (2009): Planning for landscape multifunctionality. - Sustainability: Science, Practice \& Policy 5(2): 45-52.

[80] Sitas, N., Prozesky, H.E., Esler, K.J. and Reyers, B. (2014): Opportunities and challenges for mainstreaming ecosystem services in development planning: Perspectives from a landscape level.- Landscape ecology 29(8):1315-1331.

[81] Soini, K. (2001): Exploring human dimensions of multifunctional landscapes through mapping and map-making. - Landscape and Urban Planning (57): 225-239.

[82] Stewart, P.W., Liebert, D., Larkin, W. K. (2004): Community identities as visions for landscape change. - Landscape and Urban Planning (69):315-334.

[83] Termorshuizen, J. W., Opdam, P. (2009): Landscape services as a bridge between landscape ecology and sustainable development. - Landscape Ecology 24(8):1037-1052.

[84] Tippett, J., Searle, B., Pahl-Wostl, C., Rees, Y. (2005): Social learning in public participation in river basin management-Early findings from HarmoniCOP European case studies.- Environmental Science and Policy (8):287-299.

[85] Turner, K. R., van den Bergh, C.J.M. J., Söderqvist, T., Barendregt, A., van der Straaten, J., Maltby, E., van Ierland, C. E. (2000): Ecological-economic analysis of wetlands: Scientific integration for management and policy. - Ecological Economics 35(1):7-23.

[86] Uçak, S., Külköylüoğlu,O., Akdemir, D., Başak, E. (2014): Distribution, diversity and ecological characteristics of freshwater Ostracoda (Crustacea) in shallow aquatic bodies of the Ankara region, Turkey. -Wetlands (34): 309-324.

[87] Vallés-Planells, M., Galiana, F., Van Eetvelde, V. (2014): A classification of landscape services to support local landscape planning. - Ecology and Society 19 (1): 44.

[88] Wiggering, H., Dalchow, C., Glemnitz, M., Helming, K., Muller, K., Schultz, A., Stachow, U., Zander, P. (2006): Indicators for multifunctional land use - Linking socioeconomic requirements with landscape potentials. - Ecological Indicators (6):238-249.

[89] Willemen, L., Hein, L., Mensvoort, M.E.F. Verburg, P.H. (2010): Space for people, plants, and livestock? Quantifying interactions among multiple landscape functions in a Dutch rural region. - Ecological Indicators 10 (1):62-73.

[90] Wondolleck, Julia M. and Steven L. Yaffee. (2000): Making Collaboration Work: Lessons from Innovation in Natural Resource Management. -Washington, D.C.: Island Press.

[91] Yeniyurt, C., Güler, M.F., Kandemir, A., Kılıç, D.T., Karakuş M. (2011): Ekşisu Sazlığı Sulak Alan Yönetim Planı 2011-2016 (taslağı) (Ekşisu Reeds Wetland Management Plan 2011-2016 (draft), (in Turkish)). - Doğa Derneği, Ankara, Türkiye.

[92] Zhu, X., Pfueller, S., Whitelaw, P. (2010): Spatial differentiation of landscape values in the murray river region of Victoria, Australia. - Environmental Management (45): 896-911.

[93] Zube, E. H. (1987): Perceived land use patterns and landscape values. - Landscape Ecology 1 (1): 37-45. 